\title{
遺跡の環境整備に関する実証的研究 II
}

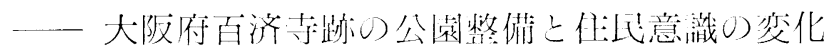

\author{
近藤 公夫 \\ A Practical Study on a arrangement of historic spot \\ Relations of the construction of Historic Park "Kudaradera \\ Old Temple" and changes of inhabitant's feelings
}

By Kimio KONDO

\section{序言}

遺跡の環境整備がもつ意義において、ひとつの課㩆は 「その整㳻が住民の遗跡に対与る理解を如何に深わ、そ の保全に積極的な参加をもつ意欲を如们に高方るか」に 求められる。さきに本報告第 1 報で、筆者は遗䟽の公園 化に関する住民意識点調查し、その学歴别、任居位置别 居住経験别分析を試みたが、ここではそれから上記㮔題

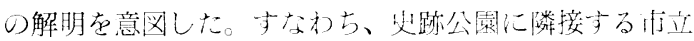
小少校の保濩者全数淍查により、約 8700 回答在得たが その約 $26 \%$ 法公洷整㳻在末外なので、これから叮能な公

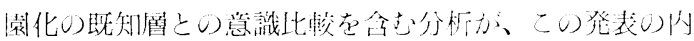
"谷である。

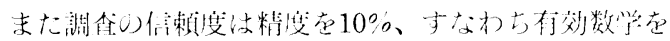

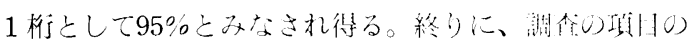

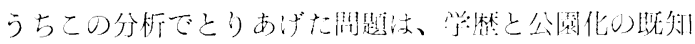

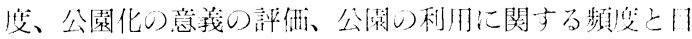

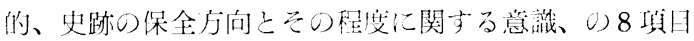
で、調查結果注約7,000型に分析された。

そしてこの型别で、調査結思が $1 \%$ 以上分在古るとみ なし得た型は8 8 型であり、学糜と利朋频度在除外した 384 型について同じく $1 \%$ 以上の分布を沃定し得九型蛙 52 型であつた。以下、調查結果を 2 項相関分析抢よび 3 項以上の相関分析にわけて説明交る。

\section{解析結果について (1)}

ここでは 2 項の相関解析結果を説明する。

i 学楚と公園化の既知度など

学歴と諸問題の関連は前報の示した通り、保全广向の

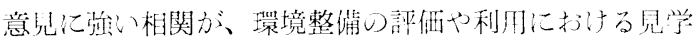
日们や保全の骀化という意識化弱い相関があること在維 渝し得るが詳述を避ける。

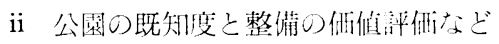

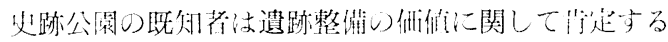

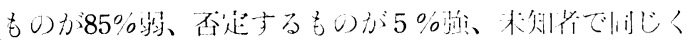

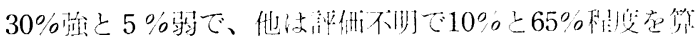

䓇良女子大学住居学科
した。

遺跡在语題にした経鈳の有無については、既知者で85 \%弱まで肯定し、未知者で $5 \%$ 弱の有経験があつただけ 这跡公㴚の利用頻度に刘して既知者注年40回水隼力゙約 15 $\%$ と年10回級約 $65 \%$ 、术知者は年10回か不明かである。

また利用目的心ついて法、畔知者の見学類似目的 $30 \%$

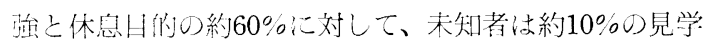

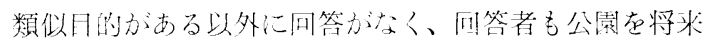
に訪㹱ならばこの目的でという仮定の回答であつた。

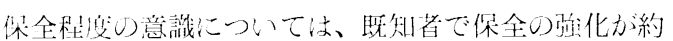

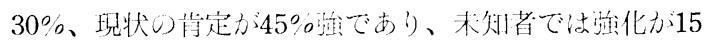

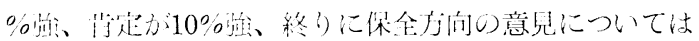

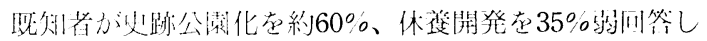

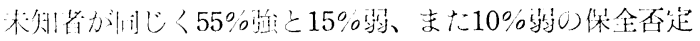
お泪答された。

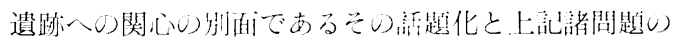

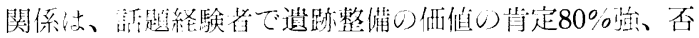

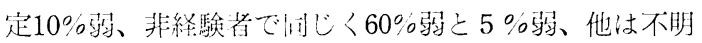
であつた。

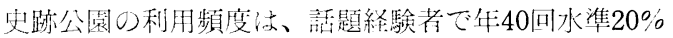
推、年10同級約 $15 \%$ 、非経験者沽同心く $5 \%$ 驹、30\%弱 他は0回ないし不肳で、その利用日讪は、前者で胃学類 似目的心約 $30 \%$ 、休息目的 $65 \%$ 弱、後者か同し人 $20 \%$ 妈 と約 $25 \%$ 、他注不明であつた。

保全程度について泳、話題経験者で保全の強化が約30 $\%$ 、現状の肯定が $45 \%$ 弱、非経験者が同じく約 $20 \%$ と 25 \%永であり、終りに保全の方向の意見蚛、前者で史跡公

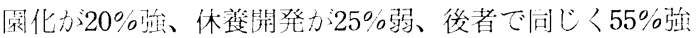

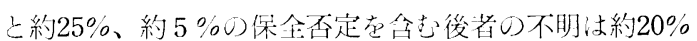
で、解者の4 倍である。

以ト、この解析も諸间題との相関は高い。

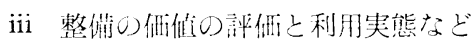

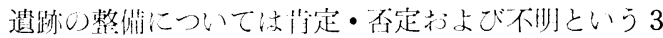

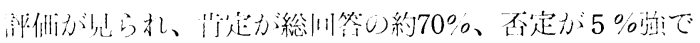

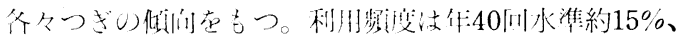

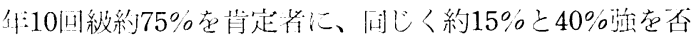
定者に、间しく各々約 $5 \%$ 在不明问答者に胃、その目的 


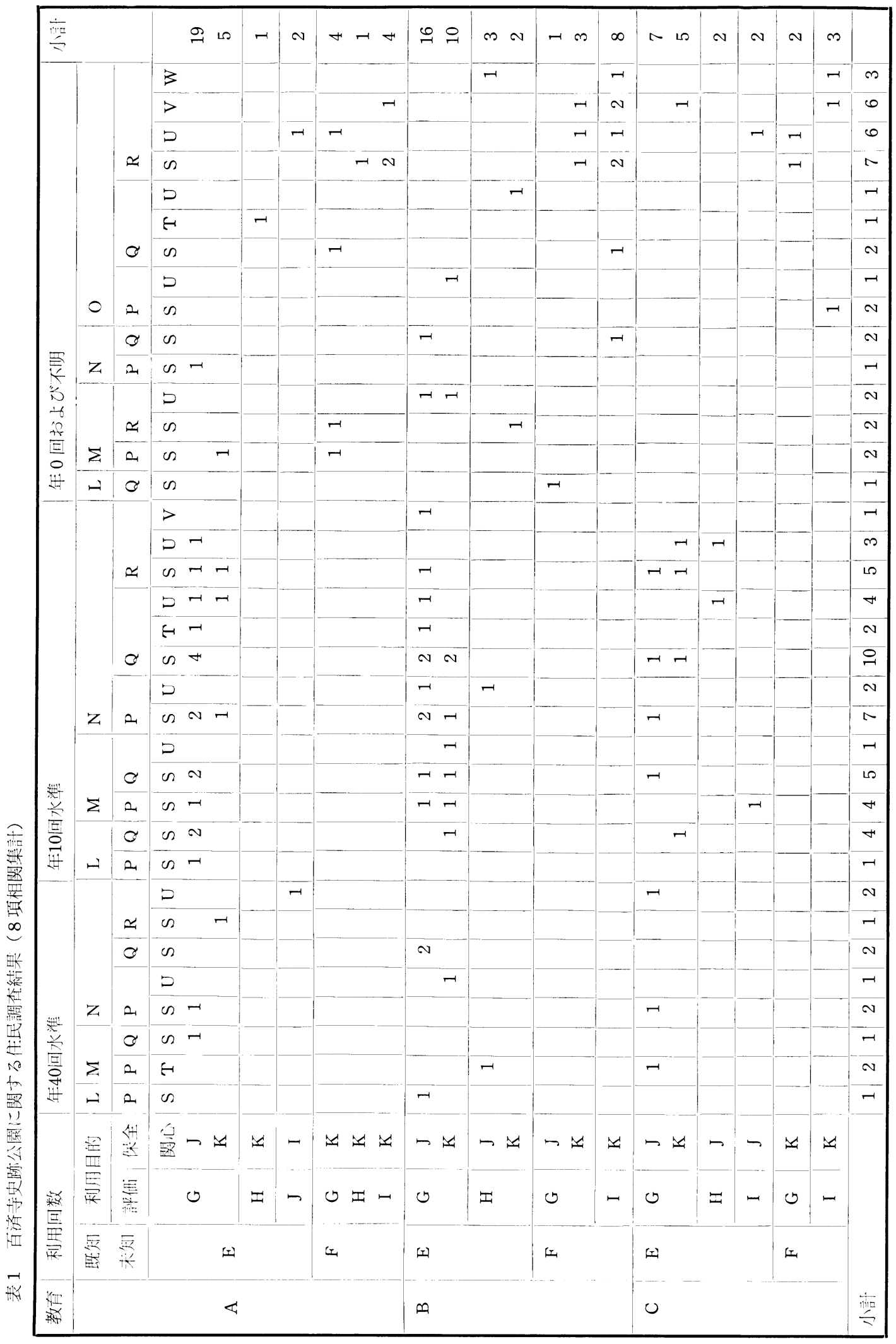




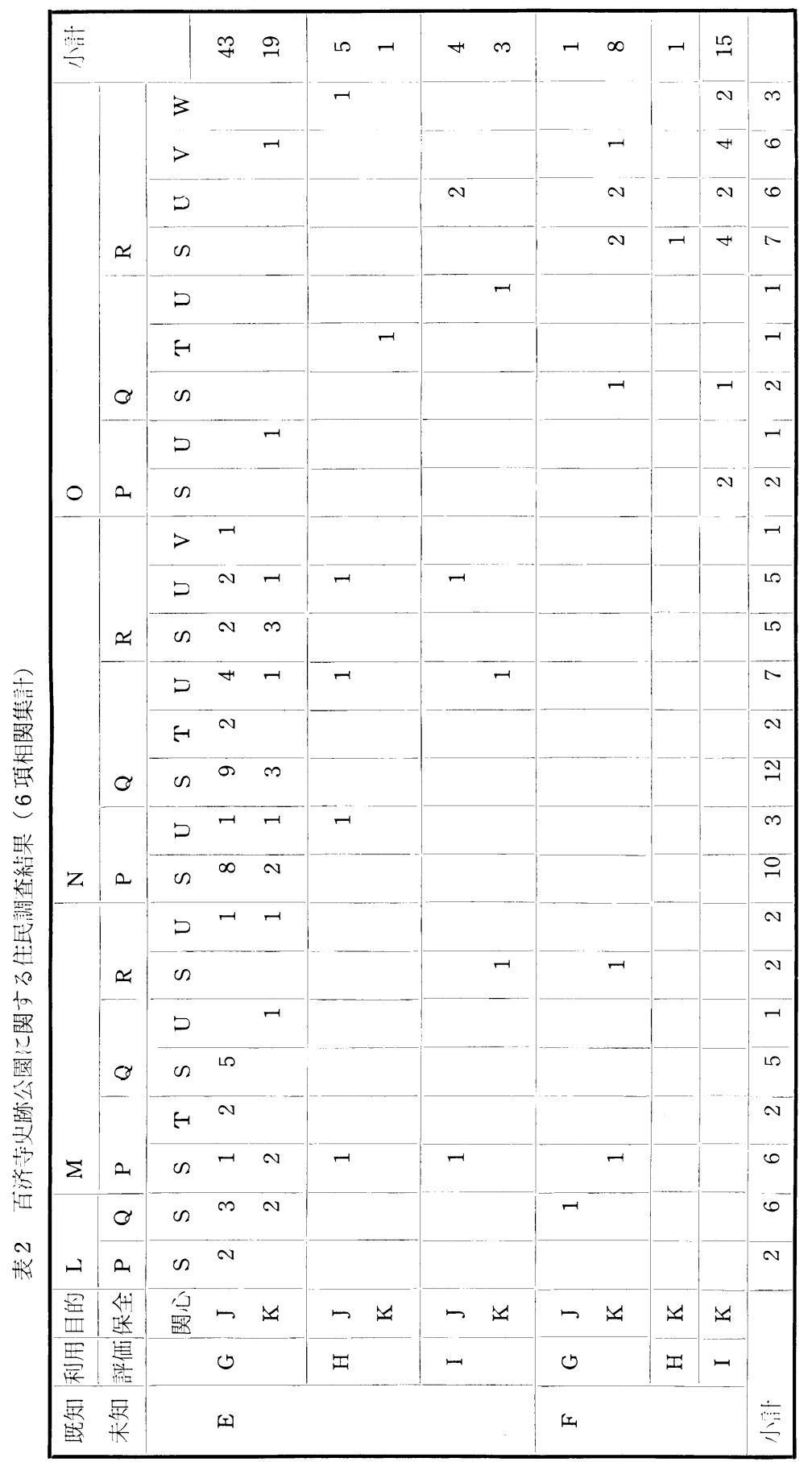

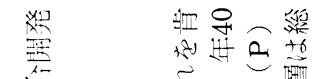

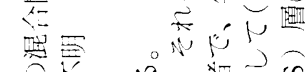

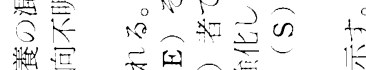

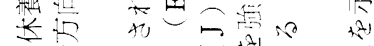

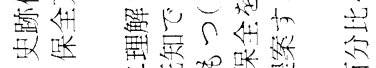

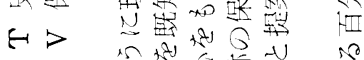

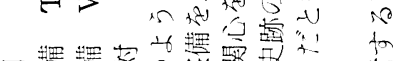

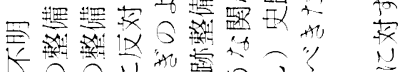

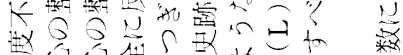

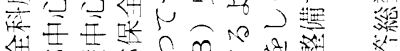

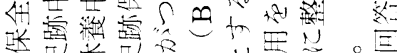

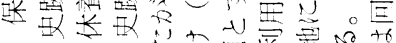

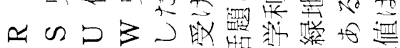

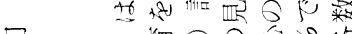

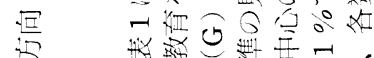

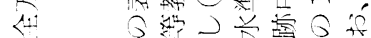

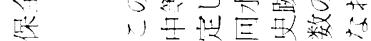

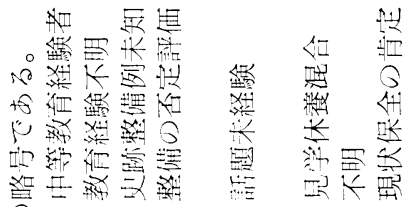

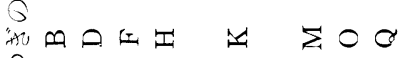
$\int_{t \rightarrow \infty}^{+\infty}$

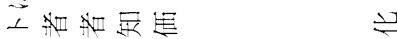

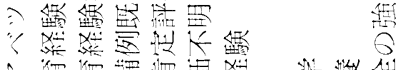

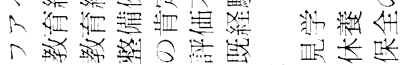

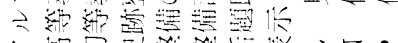

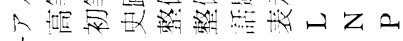
如

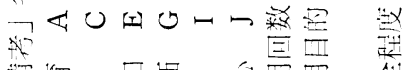

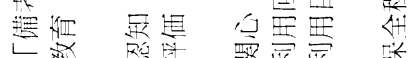

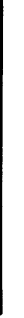

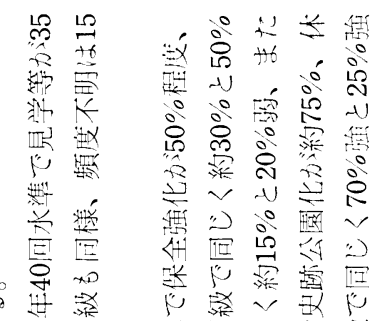

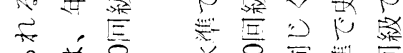

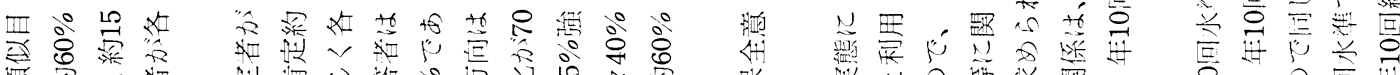

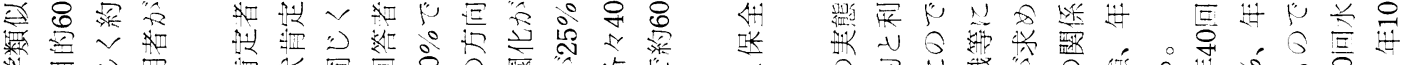

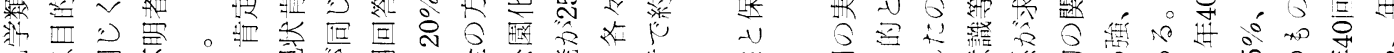

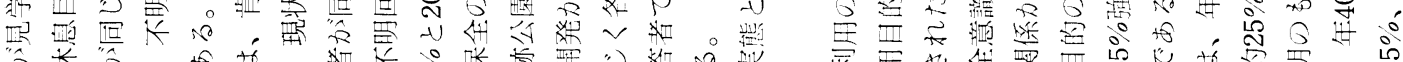

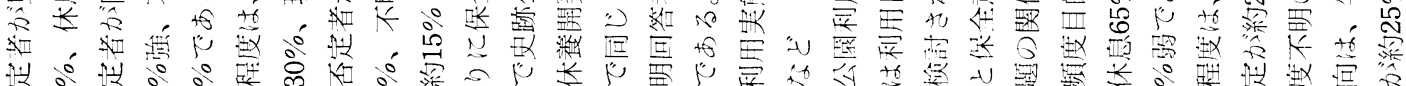

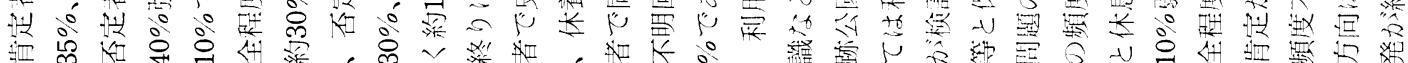

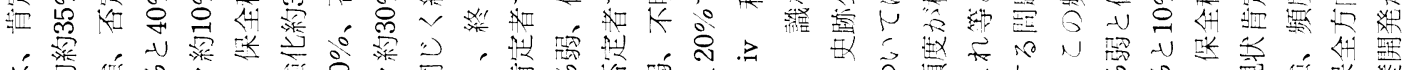

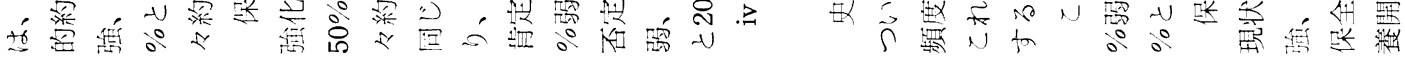




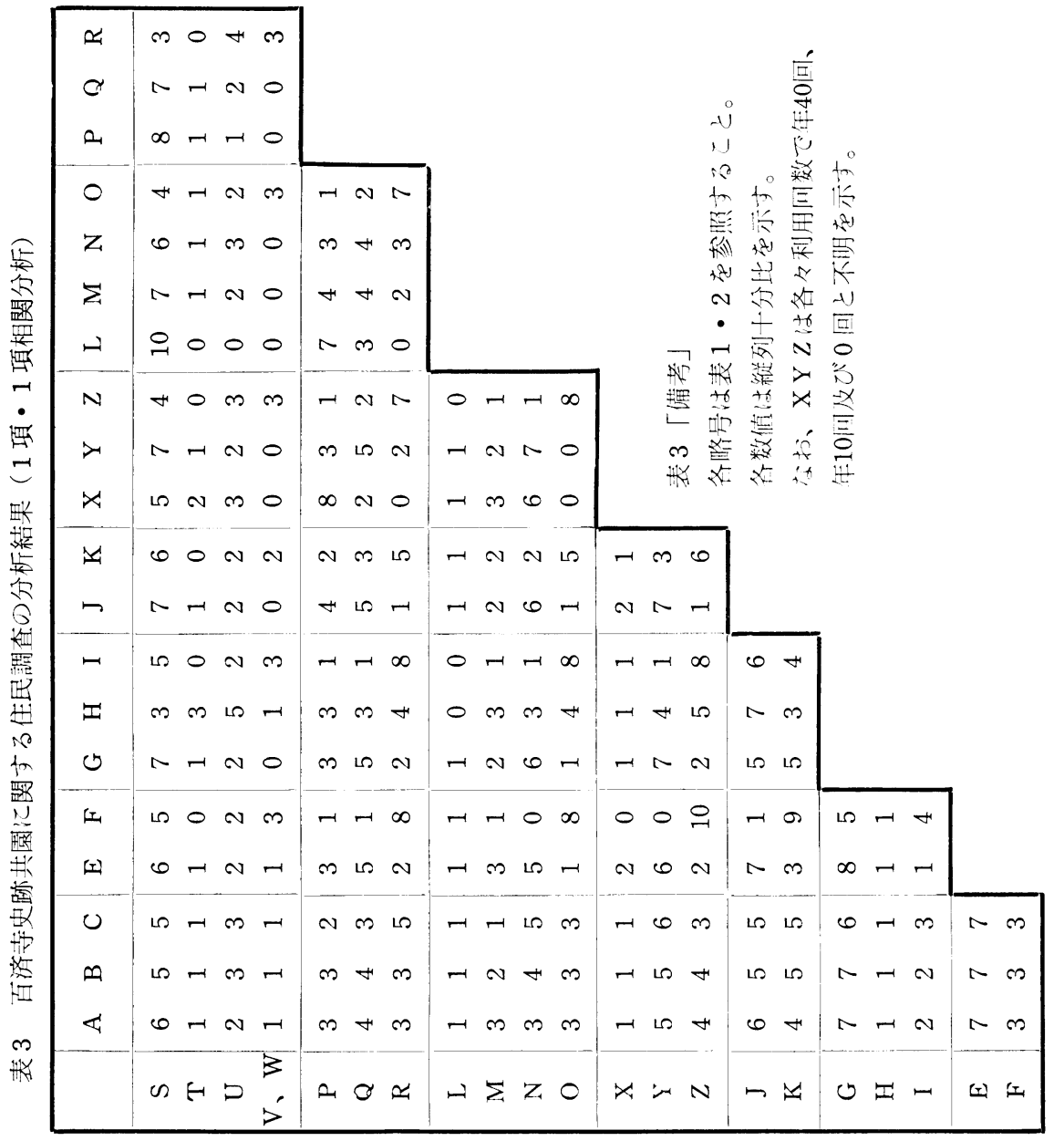

गמ

to 62

t) $x$ is

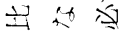

息

to

$\geqslant 0$

- 5 占

山N会主

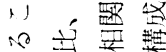
th造器 E: in

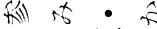
(4) $S$ 渻 $N$ N ᄀ - 式标

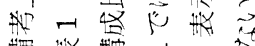
进䑪叛N, - to to N

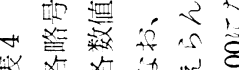

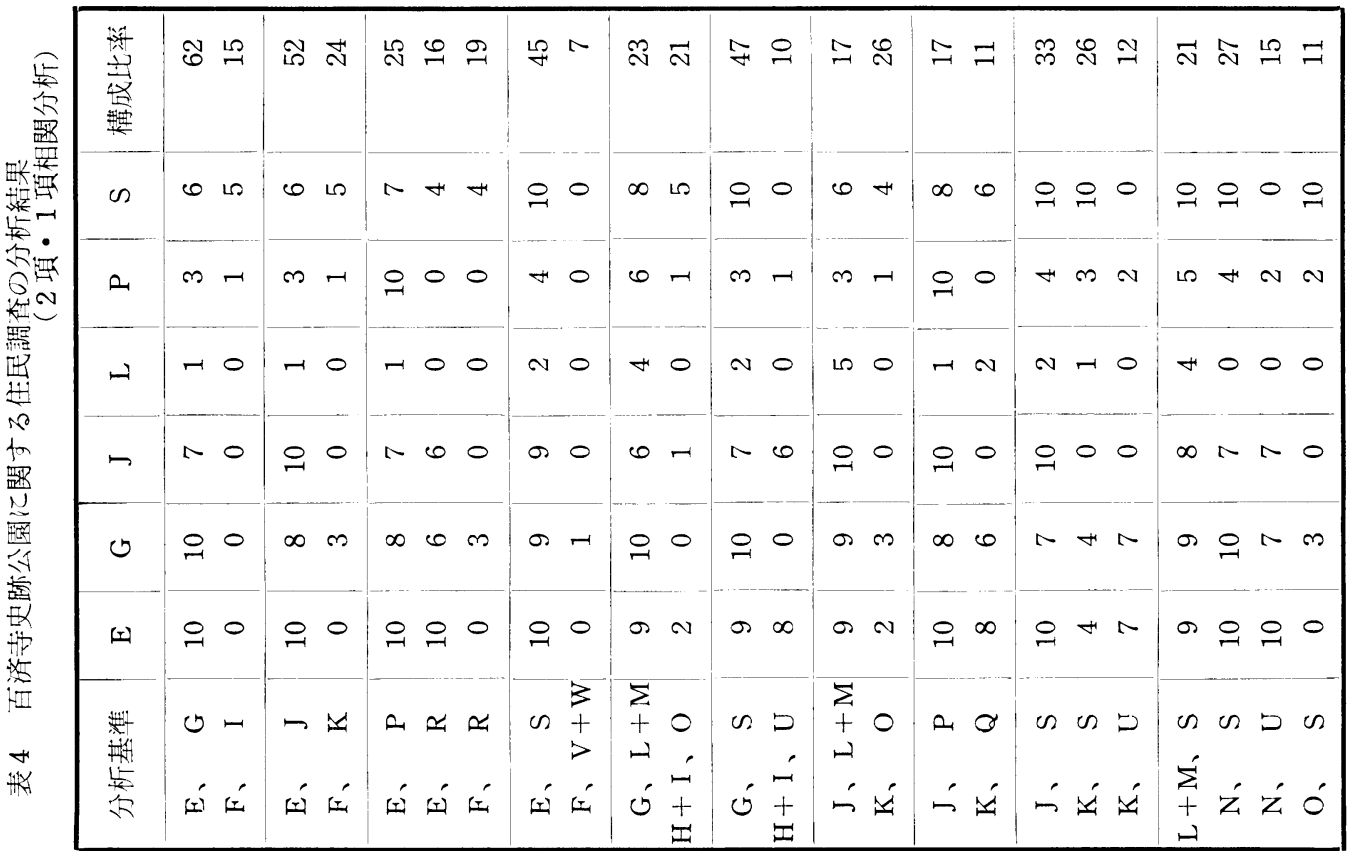


頻度不明のもので約 $45 \%$ と約 $30 \%$ である。

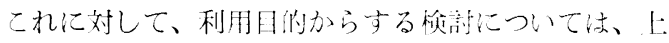

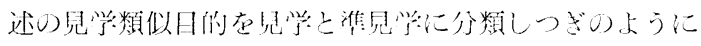
解析される。

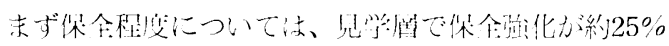

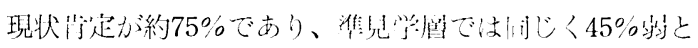

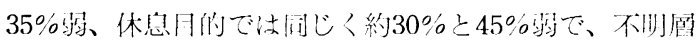
汁各々約10 と15\%弱であつた。

また利用目的と保全方向との関係法、見学馗で全数が

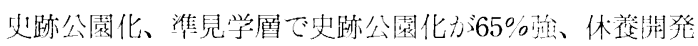
との例存や休得開発が各々約 $15 \%$ 、休息目的では条方问 が約 $60 \%$ 、5\%羽、約 $35 \%$ 、不明屏で各欠か $40 \%$ 弱、5 $\%$ 弱、30\%弱で、休蒦開発希空增が著しい。

以上の利用実態と意識との関係から法、利用目的と遗 跡保全の方问意識に相関が著しい。

これ站保全程度と方向にわける、保全强化層の史跡公 園化約 $75 \%$ 、併存開発 $10 \%$ 弱、休養開発 $15 \%$ 強、現保全 肯定の同しく $65 \%$ 强、10\%录、約 $25 \%$ 、不明の同に゙く40 $\%$ 弱、0\%、35\%㸃という関傒と同积度の相関でもあ る。

\section{$\mathrm{V} 2$ 項相関解析の総㖞}

以にの分析を通じてつぎの総括を得る。

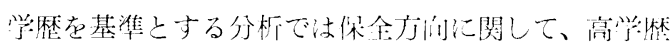

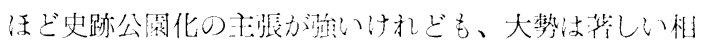
関性在示さない。

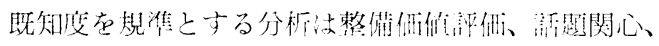

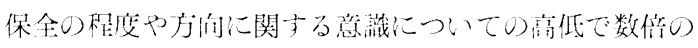

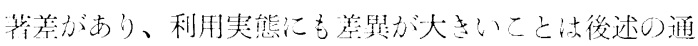
りである。

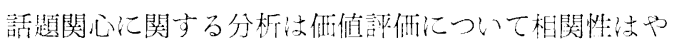
や低いが、保全に関守る意識や利用実態で法既知度によ る分析と同じく、不関心に多い不明の网答圭会み、大き い差異がある。

既知度や関心之同様、その認識に関子る問題である整 踊の肯定否定と他の間题の間に法、利用目的・保全方向 の雨者に相関がある。

他方、利用実態と意識に関する問題で结、利用頻度と 保全程度や利用目的と保全方向に相関のあること等がそ の主なものである。

以上を既括与ると、史跡公園化の既知度と話題関心の 有無と保全方问の3 者に上る分析に上り、問题の傾向纲 最も明確になると思われる。

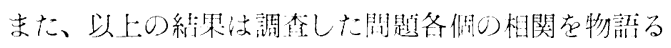

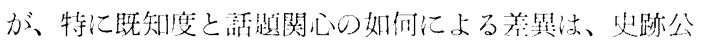

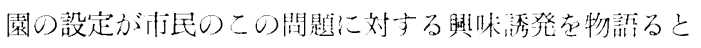
思われる。

すなわち、睤知・関心層法全数の過半であるか整㳻の

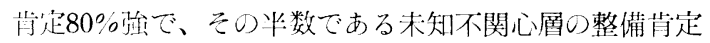

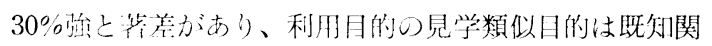

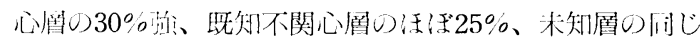

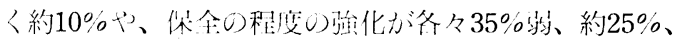

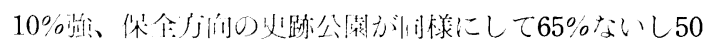
\%となる等が知れよう。

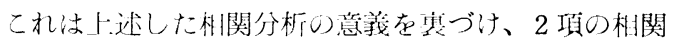
分析から多項のそれ袁発想させる。

ここで沽既知度や関心などの有意差の薄しい6 項目で 特に㫦问の明らかな10関係の2 項相関分析から、つぎの 多項分析力挰案される。

既知度・関心度罟基準とするもの

既知度・評俩度を基集とするもの

㽣知度・保全程度を基準と学るもの

既知度・保全方向基準と军るもの

関心度・利用目儌を基準とするもの

関心度・保全程度を基準とするもの

関心度・保全方向を基準とするもの

評㑛度・利用目侧を基準とするもの

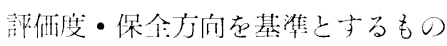

利用日似・保全方向在基售とする多の

な㧍、この研究において最も興味がもたれた史跡公園 整借の㢳知と未知による意識の差は、既知層を基準とし てつぎの通りである。

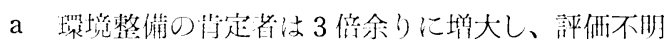
法約 7 分の 1 亿減ずる。

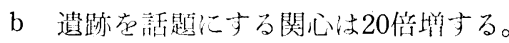

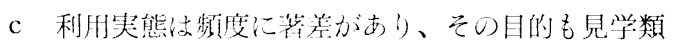
似月的が 3 倍余りに增大し、不明のものは約10分 の 1 となる。

$\mathrm{d}$ 保全程度では保全強化の主張が 2 倍增し、不明屏 汸約 3 分の 1 亿減少衣る。

e 整備の方向に関しては不明ないし保全の否定が 6 分の 1 程度に減少する。

すなわち、遺跡環境の公園化という事態はその事業の

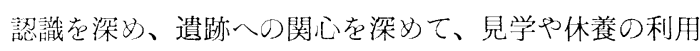
在促し、遗跡の保全強化という世論を高め、保全の方向 に緑地化等という明確な概念を与えると判断される。

この諸問題との相関性は多くが学楚々諸問題との相関 性より高く、史跡公園との接触がもたらす影響の大きさ を物語る。

\section{解析結果について (2)}

多項の相関解析法まず 3 項の相関解析、つぎに 4 項以 上のそれを試みる。

i 公園化の既知度・史跡関心度について

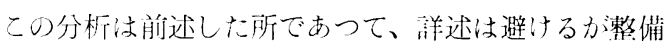


の肯定否定及び利用目的や保全程度に相関がある。

ii 公图化の既知度・整洲呯俩汇ついて

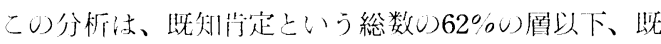

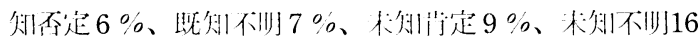
$\% 0$ 冬㬝を基售と与る。

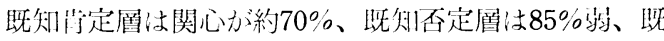

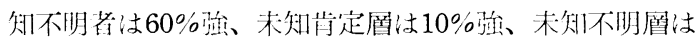
$5 \%$ 治で、その分析の有意性㳉関心度のそれと闹程度と 了想される。

まず利用目啲との関係注、见学類似目的が上述の各首 に扑て約 $30 \% 、 15 \%$ 強、15\%弱、30\%強、および0\% であつて、休養目的の同じく65\%弱、約 $50 \%$ 、約 $30 \%$ 、 $0 \%$ よび5\%強と併考し有意差が見られる。

保全程度とは、上述の各層別汇保全強化か3 $30 \%$ 強、35 $\%$ 弱、15\%弱、10\%強、10\%強、現状肯定の $45 \%$ 強、35 $\%$ 弱、30\%弱、30\%弱、10\%強という数值と共治強い相 関走示与。

終りに保全方向之の関係注、同様に史跡公園化を中心 とするものが70\%妈、0\%、30\%弱、65\%弶、および 45 \%弱であり、相関か漒い。

iii 公围化心既知度・保全方向について

乙扎注既知・史跡公固化の全数中50\%、既知休養開発 の $22 \%$ 、未知・史跡公閔化の $14 \%$ 、未知・休養開発の 4 \%考基集の分析である。

まず関心性との関係法、既知・史跡公图化層の䛻题化

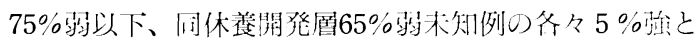

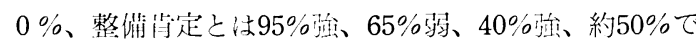
ある。

つぎに利用目的との関係流見学類似目的において上述 各層が $45 \%$ 强、15\%弱、約 $20 \% 、 0 \%$ であり、保全程度 亿ついては強化の提案が各々 $35 \%$ 弱、約 $20 \% 、 20 \%$ 強、 $0 \%$ となる。すなわちこの分析では、関心・評価・利用 目的・保全程度住対与る諸問題それぞれ亿相関があり、 この種の傾向は既知度と保全程度の関係汅もつぎのよう に見られる。

iv 公園化の既知度・保全程度について

乙の分類基準にお汀る構成法、既知保全強化層 $23 \%$ 、 既知現状肯定層 $33 \%$ 、既知不明層 $20 \%$ 、未知不明首 $18 \%$ を主要なものとする。関心度としての話題経験性各々 70 \%䏝、約 $70 \%$ 、約 $65 \%$ 、扔上び0\%で既知未知の差があ

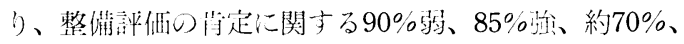
および35\%河名闹様である。

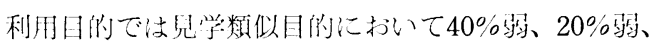
約 $15 \%$ 、抒よび0\%であり、保全方向について汶史跡公 阔化を中心として $87 \%$ \%算、約 $75 \%$ 、約 $30 \%$ 、お上び $45 \%$

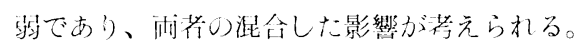

$\mathrm{v}$ 史跡公園への関心・利用目的について
この基潐の構成は関心見学類似目的 $16 \%$ 、関心休養日 肑 $32 \%$ 、不関心不明 $26 \%$ が主要なもので、諸問題との関

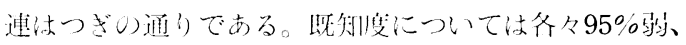

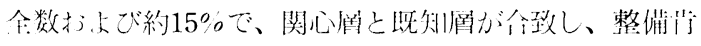
定も冬々約 $90 \%$ 、85\%掏、約 $30 \%$ である。

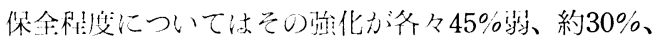

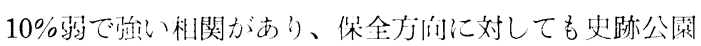
化の方问について冬々約 $95 \%$ 、70\%弱および45\%弱と相 関力漒い。

vi 史跡公囯への関心・保全程度について

この基準における構成注関心保全強化層か $17 \%$ 、関心 現状肯定層か $24 \%$ 、不関心保全強化層か $9 \%$ 、不関心現 状肯定圈が $14 \%$ である。既知度との関係法各々全数、95 $\%$ 強、65\%強および80\%弱、整備の評価では肯定か $80 \%$ 弱、95\%強、65\%强、60\%弱で相関は低い。利用目的で は見学類似目的において各々 $60 \%$ 強、約 $50 \% 、 35 \%$ 弱、 約 $20 \%$ で関心度にやや偏した相関があり、保全方向では 史跡公園化を中心と方るものが各々 $90 \%$ 弱、85\%強、80 $\%$ 弱、60\%強あつて相関沽強くない。

vii 史跡公園一の関心・保全方向について

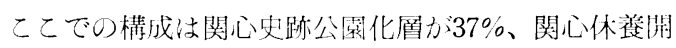
発層か $14 \%$ 、不関心跡公園化層 $27 \%$ 、不関心休鉒開発 層 $12 \%$ あ゙あ。

関心史跡公固化層以下の各層と既知度との関係沽各々

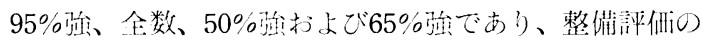

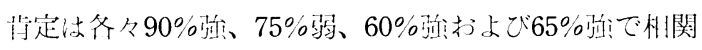
法低い。

また利用日的に関して注見学類似目的か济々約 $40 \%$ 、 約 $10 \% 、 20 \%$ 掏、20\%弱で相関か溞人、保全程度でも保 全強化が各々約 $40 \%$ 、約 $15 \%$ 、30\%弱、15\%強と同様で ある。

viii 史跡整備の評価・利用目的について

乙の基準の構成岵肯定見学類似目的層 $23 \%$ 、肯定休荃 目们層 $39 \%$ 、否定不明休養類似目的層 $11 \%$ 主要なもの である。

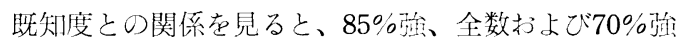
関心度との関係では約65\%、70\%巽および約 $55 \%$ で何れ も相関住低い。

また、保全程度に対しては $30 \%$ 㔖、25\%骀、約 $35 \%$ の 保全強化を各首に求㧹、保全方问としては史跡公園化

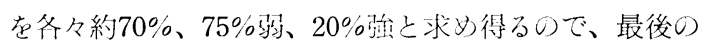

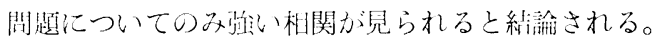

ix 史跡整供の謤任・保全方向について

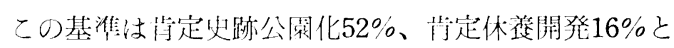
否定不明史跡公園化 $12 \%$ である。的既知度との関係汁

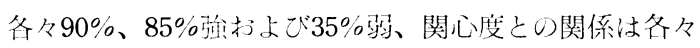
$70 \%$ 弱、約 $50 \%$ および約 $25 \%$ で相関か漒い。 
末た利用月似に対しては見学類似目か $40 \%$ 弱、約 $20 \%$ 打比び約 $25 \%$ 、保全程度に関しては保全強化が約 $35 \%$ 、

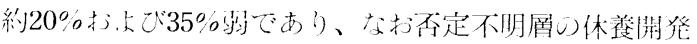

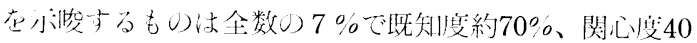

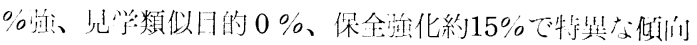
在示与。

$\mathrm{x}$ 利用目的・保全の程度机て

この基準の構成は見学類似目的史跡公图化屏の $20 \%$ 、 休養目的史跡公園化層の $27 \%$ 、同目似休瑟開発啚の17\% 目的不明史跡公園化層 $11 \%$ 主とし、まず既知度との関 係で注各々約 $80 \%$ 、全数、約 $60 \%$ 、0 \% 、関心度战約 65 \%、約 $70 \% 、 95 \%$ 弱と $0 \%$ で月们不叮首の傾向が注目さ れる。

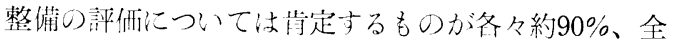
数、約 $65 \% 、 30 \%$ 弱でやや相関が兄られ、保全程度付対

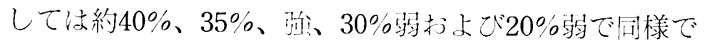
ある。

\section{xi 2 项基淮に上る 3 項分析の総括}

以上:流 2 項在基準として考元られる他項との相関の主: 装なるので、冬相関分析の10基準項目の高い相関がある 例から40型を㭘討したがその総括は以下の通りである。

これは本米前節でとりあげた 8 調查項目から得られる 168型のくみあわせに対して 4 分の 1 驹であるが、さき の相関分析で傾向の有意性が最もよく癹められたものの

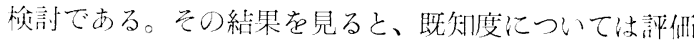

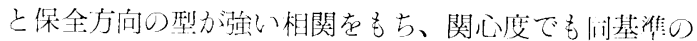
相関か漒く、環境整備の評価で结保全方向们関する基淮

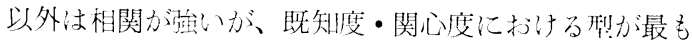
有意である。

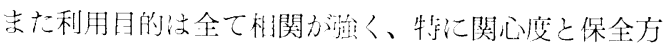
向の型が有意で、保余程度で法睡知度と保全方向や評価 存利用目约に関与る以外、特汇関心恔子利用目的の型が 有意である。終りに保全㹝的络卜沈多くの型、特に関心 度・保全程度に関子る型の分析有意性が高い。

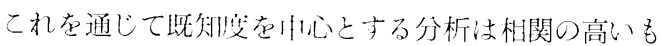
のか最も多人、保全程度の意識の气れが少な人、また、 相関の最も施いものが多いのは保全方向と関心度を中心 とする分析とみなし得、史跡公園造成の既知未知はこの 盉の䦌题の意識や行為実態㵊も著しい影響を与えると ころであり、漠然とした常識的意識である保全程度の観 念は他の意識や行為に強い関係をもたれない、と結論さ れる。

しかしながら、個々の問題に対して特治い忺関をも つ基隼としては、既知未知以後の問題である関心度など の基準があげられ、ここに多項相関分析の本米の意我が 指摘される。

xii その他の多項相関分析について
以上、この緗文では 1 項基準の 1 項分析と 2 項基準の 1 项分析在あげた。

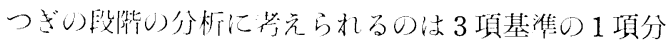

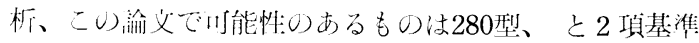

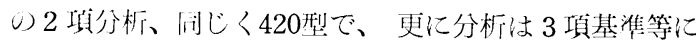
及ぶであうう。

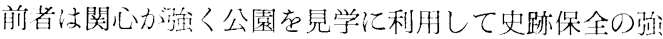
化という意識をもつような階層の既知度や評佂や史跡保 全方向の意識考考えるもの、後者注史跡公園を既知で保 全の強化を意識する階層か整備を肯定し史跡の公閨化と いう主張在もつ傾向在知る等在意味する。

上述の上うにての分析洨極めて多数型があるので、こ こでは上記の 2 例を㭘討するにとどめて以後の分析は他 の機会に㠶ずる。

関心度・利用目的・保全方向在基竍とする分析の基準 構成法、関心完学史跡公園化 $16 \%$ 、関心休養史跡公園 21 $\%$ 、関心休養休養開発 $10 \%$ 、不関心不明史跡公園化 $11 \%$ 等である。

各項の既知度は $95 \%$ 驹、全数、全数、0\%であり、そ の評価汶肖定か $90 \%$ 录沗、全数、約 $60 \% 、 30 \%$ 弱であり、 保全积度で流化が約 $45 \%$ 、40\%弱、約20\%、20\%弱で あり、評価と保全程度に関して有意の相関が見られる。

既知・保全程度を基準とするもの注既知保全強化の23 $\%$ 、既知現状肯定の $31 \%$ 、既知不明の $19 \%$ 、未知不明の 18\%在主々をる。

各项の関心・目的との関係纲関心見学に各々 $30 \%$ 虽、 $30 \%$ 弱、約 $5 \%$ 、0\%であり、関心・方向との関係胡関 心史跡公園化に $75 \%$ 弱、60\%強、10\%強、0 \% 、評倾を 中心として故評価と利用目的における肯定見学をとれば 各々 $25 \%$ 強、約 $35 \% 、 5 \%$ 強、5\%強であり、評伩と保 全方向の肯定史跡公園化江备々 $65 \%$ 弱、65\%防、25\%弱 15\%強であり、終りに利用目的保全方向任見学文跡公園

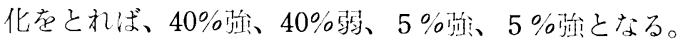

以上の 4 項目以上汇関係与る分析にあつて㹥全体在総 括する絬論を得るに至らないが、問題により異なる相関 注有意に認められる。しかし既述したように単に8 調査 項目につき分析在志ざすとの論文にあつても、相関分析 の全てをとげるには、述した多数型の 2 項相関から 8 項 相関までのくりかえしにより、人問能力をこえる分析が 要求される。

すなわち、1項基準の分析は ${ }_{8} \mathrm{C}_{2}$ をはじめとして約 1500 型、 2 項基準約7500型、 3 項基準以上約 100 型として求 められ、これ将来江子想される電子計算機を通じての 分析に期待せざるを得ない問題であろう。

\section{結語}

從来この種の質問調查は造園学に関しても利用実態や 
その意識などの問題を研究する于段として多くの例があ るが、その集計分析では単!純集垶や分析に終るものが多 く、この研究の相関分析の例法従畨られなかつた。

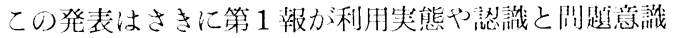
の倾向在学識や居任条件から検討したのに対し、問题相 互䦚の分析在試みる。

その絬果、つぎのくみあわせに強い相関のあることが 現在まで明らかになつた。

学歴之史跡の保全方向の関係。

史跡公撒の接触経験之整備評価・話題関心・保全程度

・保全方向㧍上び利用実態の関係。

整借の肯定・否定と利用月的・保全方向。

史跡公園在㴗勋とした関心と保全程度や保全方向わよ び利用実態の関係。

利用頻度と保全程度・利用日伯と保全方向。

以上の备 1 項閂の分析絬果として注目されるのは、史 跡環境整備の既知と末知の間における意識や利用実態の 差異であり、そこに史跡環境整储の积極似意味が考元ら れる。

他方、各項の相関分析注条 1 項開以外多项 1 项間や多 項多項間にも考元られ、約 1 万に皮ふくくあわせ全ての 検討は困難であるが、 2 項 1 項䦭の分析からつぎの検討 を得た。

整備評洒と保全方向の複合基準により史跡整備の既知 度や関心度が分析され得ること。同じ既知度と関心度の 基準が龵跡整備の評㑣と強い相関在もつこと。

関心度と保全方向の基準が利用目的と、関心度と利刀 日似が保全程度と、関心度と保全程度が保全方向と条々 相関すること。

\section{Summary}

This study is an analyse on relations of the cons truction of a historic park and inhabitants' feelings.

These are the knowledge on historic park, its valuation, interests on it, inhabitant's educational condition, using frequencies, using purposes, the level of conservation and the conservation types, as mentioned in first report.

In this study above interview's results are relatively analysed, as a relation of the knowledge of historic park and the irvaluation etc. or a relation of knowledge valuation complex and their interest etc.

As results, inteviews' answers are analysed in about 10,000 types, and the total of above analysing relations are accounted about 10,000 patterns.

At present, following conclutions are resulted, as to have clear relations.

a) educational conditions and proposes of conservation types.

b) knowledges on park and every replys.

c) valuations of parklike arrangement of historic spot and using purposes and proposes of conservation types.

d) interests on historic spot and proposes of conservation levels and types, and using purposes.

e) using frequencies and conservation levels' proposes.

f) using purposes and conservation types' proposes.

g) valuations conservation types complex and knowledges and interests.

h) knowledges-intrests complex and valuations.

i) interests-coservation types complex and using purposes.

j) interest-using purposes complex and conservation levels.

k) interest-conservation levels complex and conservation types.

Because of great mass of analysis patterns as about ten thousands, further problems will not be able to studied without computer, even in this simple study.

(42.8.10受付) 